\title{
A Reincidência Criminal em uma Abordagem Fenomenológica: Um Estudo na Penitenciária Padrão Regional de Campina Grande
}

\section{Antonio Pereira Cardoso da Silva Filho}

Graduado em Geografia pela Universidade Federal de Campina Grande (UFCG). Mestre em Desenvolvimento Regional pela Universidade Estadual da Paraíba (UEPB) e doutorando em Geografia pela Universidade Federal do Rio Grande do Norte (UFRN). Atuação em pesquisas na área de Geografia, especificamente na Geografia da saúde e questões metodológicas. Possui interesse em discussões envolvendo filosofia do conhecimento e epistemologia da Geografia. http://lattes.cnpq.br/8366285233864172. antoniocardososf@gmail.com

\section{Tiago de Oliveira Melo}

Bacharel em Direito pelo Centro de Educação Superior Reinaldo Ramos. Atua como advogado e desenvolve pesquisas na área de Direitos Humanos, Direito Penal e Desenvolvimento, especificamente sobre violência doméstica contra mulher. Possui interesse em pesquisas interdisciplinares e metodologia do trabalho científico. http://lattes.cnpq.br/9627538830436361. tiagooliveirajusal@gmail.com

\section{Bruno Cézar Cadé}

Professor de Graduação do Centro de Educação Superior Reinaldo Ramos (Cesrei - PB). Professor de Pós-Graduação na disciplina de Execução Penal. Coordenador da Pós-Graduação em Ciências Criminais pela Escola Superior de Advocacia do Estado da Paraíba Cesrei - PB. Vice-presidente da Ordem dos Advogados do Brasil, subseção Campina Grande-PB. http://lattes.cnpq.br /5436436364826189. bruno.c.cade@gmail.com

RESUMO

Esta pesquisa objetiva analisar os fatores inibidores e propulsores da reincidência criminal nos discursos da sociedade civil e dos apenados reincidentes da Penitenciaria Padrão Regional de Campina Grande-PB. Para tanto, foram adotados os seguintes procedimentos: caracterização do ambiente de estudo; levantamento documental; aplicação de questionários. No que se refere à percepção do apenado, foram destacados como propulsores: condições do presídio, convívio com criminosos, falta de emprego, falta de políticas do governo, dependência e tráfico de drogas, nenhuma condição financeira, falta de apoio da sociedade, preconceito e revolta pela lentidão do processo. Já como fatores inibidores, estes ressaltaram: relação familiar, possibilidade de emprego, sentimento de insegurança física e mental, inimizades dentro do presídio, situação de encarceramento e condições do local. Quando comparados os discursos destes sujeitos com os da sociedade civil, coincidem como propulsores: o preconceito, a falta de emprego, a dependência de substâncias psicoativas, as políticas de ressocialização, as condições do presídio e o convívio com outros criminosos. Vale ressaltar que as características pessoais do apenado, a ausência de Deus e de perspectivas foram propulsores indicados apenas pela sociedade civil. No que respeita aos aspectos inibidores, 0 único elemento coincidente entre os dois discursos foi a possibilidade de emprego.

Palavras-chave: Reincidência criminal. Percepção social. Fenomenologia. Direito. Campina Grande-PB.

THE CRIMINAL RECIDIVISM ON A PHENOMENOLOGICAL APPROACH: A STUDY AT PENITENCIÁRIA PADRÃO REGIONAL OF CAMPINA GRANDE

ABSTRACT

This research aims to analyze the increasing and decreasing factors of recidivism in the discourse of civil society and recidivist convicts of Penitenciária Padrão Regional de Campina Grande-PB. Therefore, the following procedures were adopted: characterization of the learning environment; documentary survey; questionnaires. Regarding the perception of the convict, there were highlighted as propulsior: the prison conditions, contact with criminals, lack of jobs, lack of government policies, drugs dependence and trafficking, no financial condition, lack of society support, prejudice and revolt by the slow process. Yet as inhibiting factors, they emphasized: family relationship, possibility of employment, sense of physical and mental insecurity, enmities inside the prison, incarceration situation and prison condition. Moreover, when compared the speeches of those individuals with civil society coincide as prejudice upgraders, lack of jobs, the psychoactive substance dependence, resocialization policies, the prison conditions and the association with other criminals. It is noteworthy that the convict personal characteristics, the God absence and lack of perspectives were stimulated factors indicated only by civil society. In reference of inhibitors aspects, the only common component between the two speeches was the possibility of employment.

Keywords: Criminal recidivism. Social perception. Phenomenology. Law. Campina Grande-PB.

1 Introdução. 2 A Ciência Jurídica e os Métodos Científicos: Uma Aproximação Necessária Para a Prática das Pesquisas em Direito. 2.1 A Fenomenologia Existencialista de Sartre e os Estudos do Direito. 2.2 Uma Concepção Normativa e Fenomênica da Reincidência Criminal. 3 Percurso de Investigação. 3.1 Caracterização do Ambiente de Estudo. 3.2 Levantamento Documental. 4 Os Inibidores e Propulsores da Reincidência Criminal: Os Discursos da Sociedade e dos Apenados Reincidentes em Foco. 4.1 Os Reincidentes da Penitenciária Padrão Regional de Campina Grande-PB. 4.2 A Reincidência Criminal na Percepção da Sociedade Civil. 4.3 A Reincidência Criminal na Percepção dos Apenados Reincidentes. 4.4 Visões Acerca dos Propulsores e Inibidores da Reincidência: Oposições e Complementaridades. 5 Considerações Finais. 6 Referências. 


\section{INTRODUÇÃO}

Esta pesquisa parte do interesse em compreender a reincidência criminal de maneira menos fragmentada e disciplinar, reconhecendo tanto os aspectos normativos quanto os sociais que caracterizam este fenômeno na realidade brasileira. Não se trata aqui de um estudo analítico e dogmático acerca da reincidência, mas de uma tentativa, dentro de um plano empírico e fenomenológico existencialista, de investigar os inibidores e propulsores da reincidência criminal.

Inicialmente, quando se fala em reincidência criminal, destaca-se a grande quantidade de pessoas que voltam a infringir as normas penais mesmo depois de experienciar uma situação de encarceramento em instituições prisionais no Brasil. Este contexto, em tese, é associado na doutrina e na literatura, em geral, a vários fatores, entre os quais destacam-se a incapacidade de ressocialização do apenado graças à falência do sistema prisional, as inúmeras condições de desigualdade e iniquidade social que colocam alguns grupos de indivíduos em condições de risco e vulnerabilidade social, além da própria estigmatização da sociedade com o apenado.

Diante da complexidade destas discussões, percebe-se a formação de uma arena na qual a responsabilidade pelo constante aumento da reincidência criminal é vinculada em diferentes proporções ora ao Estado, ora especificamente ao sistema prisional, ora à sociedade. No que respeita ao Estado, fala-se do não atendimento das necessidades básicas como educação e moradia, o que colocaria determinado grupo em situação de vulnerabilidade ao crime no processo de socialização e ressocialização. Já o sistema prisional, como uma instituição do Estado, é reconhecido pela ineficácia quanto ao processo de recuperação do apenado, sobretudo pela falta de estrutura. A sociedade insere-se nesta ótica a partir da construção de ideias e práticas, muitas vezes, caracterizadas pela segregação e discriminação sustentadas em um sistema cultural segregador, desconsiderando parcelas populacionais em seus contextos sociais específicos, como é o caso do ex-presidiário.

Assim, compreender até que ponto estas diferentes dimensões da estrutura social podem inibir e promover a reincidência criminal se constitui um desafio teórico e prático, principalmente pela diversidade de elementos que explicam este fenômeno. Em primeiro lugar, esta busca possibilita pensar na estruturação de políticas públicas e normas jurídicas de reinserção social que considerem a complexidade da realidade, atentando para todo o processo que corrobora a prática do crime, uma ou mais vezes, e o cumprimento da pena. Essa percepção foge de um pensamento positivo do Direito e apresenta grande potencial para a formulação de novas ideias e perspectivas de estudos transdisciplinares no campo jurídico, extremamente importante para o progresso do conhecimento na área.

O desenvolvimento deste tipo de pesquisa pode favorecer a ampliação de um olhar menos unilateral para se discutir a questão da reincidência criminal na medida em que se preocupa com a análise de diferentes discursos e das dimensões, objetivas e subjetivas, que envolvem a questão. É nesse cenário que passa a ser importante analisar como os diferentes atores sociais compreendem a reincidência criminal, especialmente por meio dos fatores inibidores e propulsores para a sua efetivação. Logo, surgem alguns questionamentos norteado- 


\section{Humanos e \\ Democracia}

res para esta pesquisa, entre os quais se destacam: Quais os fatores propulsores e inibidores da reincidência criminal na percepção do próprio reincidente? E da sociedade civil? Como as condições do sistema prisional são evidenciadas nesses discursos?

Assim, esta pesquisa tem como objetivo analisar os fatores inibidores e propulsores da reincidência criminal nos discursos da sociedade civil e dos apenados reincidentes da Penitenciaria Padrão Regional de Campina Grande - PB (PPRCG), especificamente identificando o quantitativo de reincidentes da PPRCG; compreendendo como estes apenados percebem os fatores que inibem e promovem sua situação de reincidente e avaliando os aspectos que a população destaca como os mais propulsores e inibidores da reincidência criminal.

Trata-se de uma pesquisa de abordagem qualiquantitativa. Utilizaram-se diferentes técnicas de coleta de informação e dados, como o levantamento documental e a aplicação de questionários, além da análise de conteúdo. Buscando atender aos objetivos traçados, foi viabilizado um longo trabalho de campo para a coleta de informações e dados tanto dos apenados reincidentes quanto da sociedade civil a partir de critérios preestabelecidos.

Ademais, este documento encontra-se dividido em três etapas, além desta introdução e das considerações finais. Na primeira são tratados os parâmetros teórico-metodológicos que guiaram a elaboração deste trabalho, além dos fatores normativos e fenomênicos que envolvem o instituto da reincidência criminal. Já a segunda etapa consiste na descrição dos critérios, técnicas de coleta de informação e dados, além do procedimento de análise utilizado com base no trabalho de campo. Por fim, a terceira e última etapa apresenta os resultados quanto aos discursos da sociedade civil e dos reincidentes acerca dos fatores inibidores e propulsores da reincidência criminal.

\section{A CIÊNCIA JURÍDICA E OS MÉTODOS CIENTÍFICOS: UMA APROXIMAÇÃO NECESSÁRIA PARA A PRÁTICA DAS PESQUISAS EM DIREITO}

Há séculos várias doutrinas e teorias filosóficas vêm influenciando o desenvolvimento da ciência em suas mais variadas áreas. Esta questão nos coloca diante de uma gama de possibilidades distintas de visualizar um mesmo fato, dependendo da abordagem positivista, idealista ou crítica que se decide adotar como forma de apreender tal realidade.

A este processo que possibilita, além de uma simples visualização, uma forma de mensurar, analisar e interpretar a realidade vivida, tratamos nesta pesquisa por método. Baseado no uso da razão, o método é caracterizado no século 17, inicialmente por René Descartes, a partir de uma universalidade na sua aplicação em todas as áreas. Pautado no rigor matemático, este importante filósofo da modernidade consolida uma visão integrada à racionalização e no consequente distanciamento dos sentidos e interpretações subjetivas na compreensão das coisas (DESCARTES, 1985).

Na ciência jurídica, este pensamento teve grande adesão e importantes desdobramentos. As bases do Direito moderno, nessa perspectiva, mostram-se fortemente alimentadas por um legalismo positivista que, entre outras características, acabava por resumir o Direito à lei. Esta questão, na atualidade, apresenta grande relevância entre os pensadores do Direito, suas críticas à tecnicidade e ao campo de atuação desta ciência (CLÈVE, 2001). 
Nesse contexto, quando se pensa no neopositivismo do século 20 aplicado ao Direito, não há como deixar de recorrer ao pensamento de Hans Kelsen. Este autor, acreditando haver uma confusão entre política e Direito, assegurava que a subordinação do Direito a ideologias acabava inviabilizando o desenvolvimento científico deste ramo do conhecimento. A neutralidade, assim, deveria ser um pressuposto norteador para os estudos jurídicos (BOBBIO, 1995). Ademais, como afirmava Kelsen (1997), a preocupação do Direito deveria ser exclusivamente com as questões da normatividade, destacando que nesse momento, inclusive a própria hermenêutica jurídica deveria abandonar seu caráter idealista. A principal contribuição deste autor diz respeito à elaboração da Teoria Pura do Direito, distanciando-se da compreensão do Direito como fato social, sustentando uma base para o aprimoramento de uma ciência positiva.

Costa (2008), a partir de sua tese de Doutoramento na área do Direito, avalia momentos históricos anteriores à construção moderna do Direito e a influência dos métodos no desenvolvimento desta ciência. De acordo com o autor, a necessidade de descrever a realidade foi ultrapassada pela necessidade de interpretá-la, incialmente por estruturas universais e invariáveis, de modo que a hermenêutica, nesse contexto positivo, era vista apenas como uma metodologia em busca de sentido verdadeiro e perceptível ao homem.

Vários filósofos modernos, no entanto, dedicaram grande parte da sua contribuição intelectual à discussão de uma hermenêutica e fenomenologia mais integrativa, entre a realidade concreta e a sua interpretação, especialmente em um contexto cultural e historicamente construído. Heidegger (2002), no século 19, representando uma corrente filosófica existencialista, afirmava que o ser era determinado pelo onde, logo toda a capacidade interpretativa do sujeito era comprometida com o seu modo de ser no mundo, variando em cada lugar e tempo, destacando-se as inúmeras especificidades dos sujeitos na leitura do que é a própria realidade.

No século 20, Sartre (1987) propõe uma discussão, que também corrobora esse esforço teórico, de compreender a realidade a partir de concepções objetivas e subjetivas. Este filósofo reconhece que os processos objetivos da evolução social se impõem a todos os homens, porém com diferentes reflexos. Pelo fato de a existência prescindir a essência, cabe ao homem e as suas escolhas construir sua própria essência. Este autor representa uma significativa contribuição não só ao pensamento hermenêutico, mas também ao método fenomenológico que trataremos posteriormente neste trabalho.

Partindo desse pressuposto, cabe pontuar a diferença entre hermenêutica e fenomenologia. Mesmo reconhecendo a complexidade que envolve esta discussão teórica e filosófica, nos arriscaremos em uma tentativa de simplificação, que reconhece a hermenêutica como uma disciplina filosófica comprometida com a compreensão e posterior interpretação, e a fenomenologia como método científico. Assim, a hermenêutica refere-se à disciplina que busca o sentido das coisas, reconhecendo uma visão de mundo própria de um sujeito carregado de características, integrando o que compreende daquilo que é compreendido (BRITO et al., 2007).

Já a fenomenologia, destacando a perspectiva de Sartre (2000), corresponde ao método científico embasado no entendimento do que ele denomina de Para-si e em Em-si, de modo que o primeiro, a consciência, limita-se a tornar as características do segundo, o mundo, conhecido. Chega-se assim, à ideia de ser-no-mundo, concretizando a relação teórica in- 


\section{Humanos e \\ Democracia}

dissociada entre a consciência e o mundo. Logo, a fenomenologia trata-se de um método por apresentar os seus elementos constituintes e propor uma visão de mundo com suas correspondentes teorias, doutrinas, leis, conceitos e categorias.

Minayo (2004) afirma que a hermenêutica e a fenomenologia integram-se mutuamente, apesar das correspondentes distinções. Esse reconhecimento só é possível graças a profundas transformações nas bases teóricas que orientavam a própria fenomenologia. É importante destacar que, apesar de reconhecer todas as contribuições de Husserl (2001) como pioneiro da fenomenologia para além do pensamento metafísico, de uma fenomenologia hermenêutica, estamos considerando a concepção deste método desenvolvida, especialmente, por Sartre. Logo, ainda de acordo com Minayo (2004), enquanto a hermenêutica busca a compreensão e interpretação, a fenomenologia possibilita a apreensão dos fenômenos e dos fatos tais como eles são constatados na realidade empírica, de modo que não há como interpretar e compreender os processos de maneira isolada desses fenômenos.

Historicamente a hermenêutica associou-se à compreensão e interpretação de textos. Segundo Grodin (1999), tal abordagem assume-se como uma doutrina capaz de garantir procedimentos competentes de interpretação, com sua natureza sendo predominantemente técnica e normativa. Nesse sentido, a hermenêutica jurídica ganha grande destaque, sobretudo pelo desafio na compreensão, interpretação e aplicação das leis a partir de várias escolas do pensamento jurídico, porém as pesquisas empíricas de abordagem qualitativa levantam uma série de outras necessidades que precisam ser providas por meio de outros padrões de investigação. Assim, a fenomenologia revela-se uma importante alternativa teórico-metodológica no campo do Direito por apresentar uma condição ao pesquisador de avançar para além da norma, sendo evidenciados os problemas do Direito no tempo e no espaço, no universo empírico.

É importante ressaltar que as possibilidades não se esgotam ao que foi apresentado até então. A dialética, ou o materialismo histórico-dialético como método científico, também possui grande importância em meio aos debates e pesquisas científicas em Direito. Costa e Coelho (2017) em uma análise sobre a dialética, ideologia e historicidade revelam a possibilidade, por meio do método dialético, de integrar concepções, a priori, conflitantes em uma mesma compreensão da realidade menos fragmentada e desarticulada. Nesse sentido, deve-se destacar sempre pontos de referência capazes de avaliar a legitimidade do Direito, bem como ampliar uma práxis socialmente crítica e comprometida com a promoção da Justiça. Este pensamento, em síntese, traz uma série de transformações tanto no campo da legislação e aplicação da lei quanto na pesquisa científica em si.

A compreensão destes contextos é substancial para o aprimoramento da prática de pesquisa em Direito, de modo que, na ciência jurídica, é amplamente reconhecida a necessidade de trabalhar de maneira mais integrada os conhecimentos jurídicos específicos da área do Direito com os métodos e a Teoria do Conhecimento, especialmente na formação dos alunos de Graduação e Pós-Graduação, constituindo-se este um dos mais importantes desafios para a produção da ciência e da pesquisa científica na área. Não se trata aqui de uma busca abstrata e multidimensional de propor a ciência jurídica, mas sim de uma tentativa de pensar o mé- 
todo na prática da pesquisa em Direito, reconhecendo as dificuldades, ultra- especializações, nomenclaturas e a grande herança disciplinar que dificulta, ainda, uma produção científica mais orientada para a transdisciplinaridade teórico-metodológica.

Considerando-se necessário estabelecer, inclusive, uma clareza na compreensão do Direito como campo científico, destacam-se as discussões de dois importantes doutrinadores que reconhecem, paralelamente, o Direito de maneira menos centralizada na norma. A teoria tridimensional do Direito de Miguel Reale (1994) e o Direito como processo de adaptação social de Paulo Nader (2011), assim, dispõem de uma construção teórica compatível com a proposta deste trabalho, contrapondo-se à dimensão pura do Direito defendida por Hans Kelsen.

Reale (1994), desenvolvendo uma concepção paradigmática sobre o Direito no Brasil, apesar das correspondentes críticas epistemológicas, afirma que essa ciência vai muito além da norma jurídica, devendo ser reconhecida também como fato e valor. Nesse sentido, o autor reconhece toda a indissociabilidade do Direito com os aspectos objetivos e subjetivos da realidade, devendo ser compreendido em sua totalidade e complexidade. Ademais, constata-se que para Reale a aplicação da norma jurídica à realidade deve ser concebida por meio de concepções valorativas, com o fato, o valor e a norma se complementando dentro de um plano dialético construído historicamente. Ortega y Gasset (1997), filósofo espanhol contemporâneo, apresenta grande influência no pensamento de Reale, especialmente com a razão histórica e com o reconhecimento da inseparabilidade entre o eu e as coisas na determinação das características técnicas dos lugares que, por sua vez, justificam os fatos e valores das diferentes sociedades.

A percepção do Direito, na condição de processo de adaptação social, é muito discutida por Nader (2011). Para este autor, o Direito, como norma, precisa se ajustar num processo cíclico às condições da sociedade que regula, fomentando as bases da justiça e da segurança, possibilitando a estabilidade da vida social. Logo, o Direito deve expressar a vontade social, não representado a vontade individual, mas sempre da coletividade. Nader (2011) conclui que é indispensável que a lei promulgada ganhe efetividade, isto é, que os comandos sejam vividos e aplicados nos diferentes níveis de relacionamento humano. O conteúdo de justiça e o sentimento de respeito pelo homem devem ser a motivação maior para o processo de adaptação da nova lei. É válido ressaltar que a coercibilidade da lei atua, com intensidade, de forma a estimular a efetividade do próprio Direito.

\subsection{A Fenomenologia Existencialista de Sartre e os Estudos do Direito}

A grande influência de Sartre na política e no Direito é de amplo reconhecimento de vários autores das diferentes áreas do conhecimento científico. A busca por uma compreensão concreta acerca da liberdade e da ética e o desenvolvimento de uma perspectiva fenomenológica diferenciada de uma corrente puramente idealista foram importantes contribuições deste filósofo do século passado. Suas principais obras sintetizam essas correspondentes impressões.

O ser e o nada (2011), obra de Sartre publicada originalmente em 1943, consolida-se a partir das discussões sobre o existencialismo, além de sólidas reflexões acerca do Direito e da ética. O diálogo com o marxismo e a avaliação específica das constituições e das estruturas sociopolíticas também são objetos de intensa investigação do autor em posteriores obras 


\section{Humanos e}

Democracia

muito difundidas no meio acadêmico, especialmente nas ciências humanas, sociais e sociais aplicadas. A Crítica a razão dialética (2002), publicada pela primeira vez em 1960, também integra este escopo, sendo caracterizada por uma mediação entre o materialismo e o existencialismo, considerando as categorias históricas e sociais a partir de estruturas antropológicas já elaboradas em O ser e o nada (2011).

Maman (2003), realizando importante crítica ao pensamento jurídico brasileiro, por meio de uma perspectiva fenomenológica existencialista, apresenta várias contribuições de importantes filósofos dessa corrente de pensamento, entre os quais destaca-se Sartre. Discorrendo sobre o contexto histórico, cultural e ideológico que influenciou este filósofo, a autora destaca pontos convergentes entre a produção de Sartre e de outros filósofos contemporâneos, como é o caso de Heidegger. Nesse sentido, para ambos, um desígnio prioritário que deveria orientar a produção científica no Direito teria de ser a superação dicotômica construída historicamente no seio da ciência. Logo, o sensível e o inteligível, o sujeito e o objeto, a essência e a aparência não poderiam mais ser objetos antagônicos no interior da análise científica jurídica. É importante ressaltar que a diálogo entre esses filósofos apresenta uma amplitude de questões e complexidade que não se pretende tratar aqui, haja vista a necessidade de compreender os preceitos fenomenológicos como método em Sartre.

Deste modo, é nesse entendimento que buscamos discorrer simplificadamente a fenomenologia de Sartre (2000), utilizada nesta pesquisa. De acordo com este filósofo, nem a concepção realista, nem a idealista, sozinhas, eram capazes de se consolidar como uma abordagem completa sobre a realidade concreta, pois para ele a consciência e o mundo existem paralelamente, independentemente do modo como se relacionam. Estas discussões envolvendo consciência e mundo vão muito além das teses puramente realistas ou idealistas.

Em continuidade, Sartre (2000) afirma que a redução da realidade, ou do ser, à sua aparição, fundamenta-se na concepção idealista. Nesse caso, sua crítica baseia-se no fato de que o mundo dispõe de uma existência que transcende o conhecimento que temos em relação a ele, apresentando-se como subjetivo, mas também objetivamente. Além disso, a dimensão subjetiva da realidade será moldada e desenvolvida a partir do seu conhecimento objetivo. Então, na observação do mundo, constata-se uma série de elementos de quantidade e a espacialidade dos movimentos que, a priori, constituem-se apenas como uma relação de exterioridade que se ignora, existindo concretamente mesmo sem a consciência (ECKER, 2010).

No que se refere à abordagem do realismo sintetizada em dimensão objetiva e racional da ciência, Sartre (2000) institui suas críticas embasadas na ideia de que a consciência não pode ser apenas mais uma coisa que se encontra no mundo, visto que a relação entre mundo e consciência é que viabiliza a existência recíproca de ambos. Assim, ao propor sua fenomenologia, Sartre entende que tanto o realismo quanto o idealismo precisam ser considerados na elaboração desta abordagem científica, de modo que o mundo se apresenta tanto como objetivo, considerando sua existência antes que a nossa consciência o revele, quanto subjetivo, uma vez que o ser reconhecido é transportado por uma subjetividade.

No campo do Direito, como aponta Almeida (2011), essa concepção filosófica apresenta grande contribuição, a exemplo da busca por uma compreensão das condutas humanas tanto por meio do diálogo com a fenomenologia de Husserl quanto pela visão existencial de Heidegger, além da dialética incorporada às produções de Hegel e Marx. Assim, Sartre, resguardan- 
do sua forte tendência existencialista, levanta várias discussões importantes ao Direito que precisam ser vistas sob esse viés menos fragmentário da realidade, como é o caso da liberdade, do humanismo, da justiça e da política, da legalidade, das estruturas sociais, da violência, da moral e das instituições, entre outras. Deve-se, deste modo, atentar para a complexidade que envolve todas estas questões em sua essência fenomênica, existencial e dialética ao mesmo tempo.

Com destaque à influência dialética na fenomenologia de Sartre, por meio da ênfase na História, sem abandonar a visão existencialista, o filósofo descreve o Direito, ao mesmo tempo, como exigência ética e como legalidade, esta última mais vinculada aos processos jurídicos integrados à lei. Nesse caso, para Sartre, o Direito como uma condição de exigência, imposta, possibilitaria aos indivíduos caminharem em direção à própria liberdade. A preocupação do autor em pensar o Direito corresponde a uma grande contribuição teórica para a disciplina com amplas interpretações e análises. Atentando-se ao esforço na análise do método fenomenológico, não iremos adiante nessa discussão trabalhada minuciosamente, por exemplo, por Almeida (2011) na sua obra Sartre: Direito e Política, no entanto já é possível contatar as inúmeras aproximações teóricas, conceituais e, especialmente, metodológicas entre Sartre e o campo científico do Direito.

Atento às discussões propostas por Maman (2003), ressalta-se que o Direito não precisa mudar apenas na maneira como é produzido e emanado, mas deve mudar seu espírito. Isso, em tese, significa uma reestruturação quanto ao seu papel de promover a justiça e o seu alcance como disciplina. Metodologicamente, há uma necessidade, cada vez mais evidenciada, de aproximação do Direito com a realidade empírica apreendida na prática da pesquisa na área. O objetivo é a superação, definitiva, de uma agenda de pesquisa que ainda insiste em tratar o Direito exaustivamente como norma jurídica. Nesse sentido, a pesquisa em Direito também deve se ater à realidade social, às questões espaciais e temporais que envolvem certas problemáticas, ao contexto histórico e geográfico que respondem quando e onde a realidade social é composta e porque a lei se torna viável, aplicável e ganha diferentes níveis de efetividade.

Referenciando Morin (2007), é preciso buscar incessantemente um saber não compartimentado e não redutor, destacando-se que o simples não existe, mas sim o simplificado, tudo é complexo. Por isso, o intenso processo de classificação e generalizações superficiais fazem parte cada vez mais das produções nas diferentes áreas, inclusive das Ciências Humanas e Sociais. No que se deve tomar extremo cuidado é exatamente com os reflexos dessa simplificação tanto no campo jurídico de aplicação da lei quanto no campo das pesquisas científicas em Direito, de campo ou gabinete, reduzindo, nesse exercício, o abismo científico construído entre o jurista, operador do Direito, e o pesquisador, analítico do contexto social.

\subsection{Uma Concepção Normativa e Fenomênica da Reincidência Criminal}

Inicialmente, cabe ressaltar o cenário brasileiro de expressivo crescimento da população carcerária em todo o país, além do aumento progressivo da reincidência criminal. Derivada do latim recider, a palavra reincidência é composta pelo prefixo re, que dá a ideia de repetição, e o substantivo incidência, de atingir, cair sobre, tornar a praticar. O surgimento da reincidência 


\section{Humanos e}

Democracia

remonta, ainda, ao Direito Romano, em que se apresentava como agravante de algum delito, tal como o furto, cometido com reiteração. Reincidir, portanto, é repetir o ato, voltar a fazer a mesma coisa (CHIQUEZI, 2009).

A reincidência no Direito Penal brasileiro ganhou previsibilidade no artigo 63 do Código Penal nos seguintes termos: "Verifica-se a reincidência criminal quando o agente comete novo crime, depois de transitar em julgado a sentença que, no país ou no estrangeiro, o tenha condenado por crime anterior". Sendo assim, para que reste configurada a reincidência criminal deverá existir a comprovação de trânsito em julgado de sentença por meio de certidão, na qual constará a data do trânsito. A partir do Direito Penal como instrumento de coação, o legislador busca minimizar os índices de criminalidade, tornado a pena mais rígida, além de incorporar instrumentos para sua agravação, como é o caso da reincidência criminal. Esta, especificamente, tem o condão de agravar as circunstâncias processuais e penais de um indivíduo que tem a reiterada prática do crime.

Assim, a reincidência surge como: agravante da pena quando não constitui qualificadora (artigo 61, I); fator preponderante no concurso de agravantes e atenuantes (artigo 67); impedimento na concessão de sursis na hipótese de crime (artigo 77, I); impedimento nos casos de substituição da pena privativa de liberdade por restritiva de direitos, salvo nos casos em que a reincidência seja genérica e a substituição seja socialmente recomendável (artigo 44, II e artigo 44, §3ㅇ); empecilho no caso de substituição da pena privativa de liberdade por pena de multa (artigo 60, $\$ 2 \circ$ e 44, $2^{\circ}$ ); conversora da pena substitutiva em privativa de liberdade (artigo 45, I e §5ㅇ, artigo 44); imposição ao regime inicialmente fechado no cumprimento da pena privativa de liberdade (artigo $33, \S 2 \circ$, b e c), motivo de revogação obrigatória do sursis em condenação por crime doloso, entre muitas outras consequências.

Nesse sentido, a reincidência criminal possui natureza jurídica de agravante genérica que, por sua vez, tem aplicação na segunda fase da dosimetria da pena privativa de liberdade. A agravação da pena, entretanto, é somente uma de suas consequências, não sendo correto restringir sua essência somente a este efeito (CHIQUEZE, 2009). A natureza jurídica da reincidência, para Marques (1956), é de discussão da doutrina, uma vez que alguns a tratam apenas como circunstância do crime e outros a classificam como uma qualificação de cunho subjetivo do indivíduo. Por este motivo seu caráter subjetivo não incide sobre os coautores ou partícipes da ação criminosa.

Assim, em síntese, como pressuposto da reincidência, exige-se a prática de um crime após o infrator já ter sido condenado em definitivo pela prática de um crime anterior. Desse modo, de acordo com alguns doutrinadores, o instituto da reincidência não deve ser empregado quando um indivíduo, após condenação ou pena imposta pela prática de uma contravenção, comete um crime, no entanto, quando há condenação de crime transitado em julgado e o indivíduo pratica a contravenção, este é indicado com reincidente (FRAGOSO, 2004).

No que se refere à contravenção, Capez (2008) assegura definitivamente que o condenado pela prática de contravenção que posteriormente venha a praticar crime não deve ser considerado reincidente, uma vez que o artigo 63 do Código Penal faz única menção a crimes anteriores. Vindo, todavia, a praticar nova contravenção, será, neste caso, considerado reincidente para efeito da aplicação da pena . 
Outro ponto que merece destaque nesta discussão é que a legislação brasileira reconhece as condenações nacionais e estrangeiras. Neste caso, a lei não exige nenhum requisito especial para a sentença estrangeira, nem mesmo sua homologação, no entanto nem toda sentença condenatória estrangeira estaria apta a produzir os efeitos da reincidência, como assinalam Zaffaroni e Pierangelli (2002). Estes mesmos autores têm o entendimento que nestes casos, para a produção da reincidência, é exigido que a sentença penal condenatória estrangeira seja consequência de uma conduta tipificada tanto no respectivo país quanto no Brasil. Logo, se consideraria um absurdo que alguém fosse considerado reincidente em razão de uma infração cometida anteriormente entendida como atípica pela legislação brasileira. Neste caso deve ser levado em consideração o Princípio da Dupla Tipicidade.

No que se refere à justificativa para uso do agravante da reincidência criminal, a ideia mais difundida parte do pressuposto da maior periculosidade do indivíduo que voltou a cometer novo crime (ZAFFARONI; PIERANGELLI, 2002). O fundamento de quem defende tal argumento é apresentar a figura da reincidência presumida, considerada na atualidade uma incongruência jurídica, posto que a periculosidade busca suporte fático.

Outra tese suscitada para justificar a aplicação da agravante recidiva funda-se na ideia de ampliação do conteúdo do injusto do fato. Nesse sentido, a pessoa que pratica um delito após o cometimento de um crime anterior estaria afetando também a imagem de provedor da segurança jurídica que tem o Estado (BARREIROS, 2007). A ideia de insuficiência da pena imposta no primeiro delito, não evitando o cometimento de outros, forma outra tese que se estrutura em defesa da aplicação do instituto agravante da reincidência. Tal justificativa, todavia, não se sustenta na medida em que a pena, muitas vezes, funciona como condição para a prática de outro delito, e não o contrário. O fato é que a realidade social exterioriza que a pena de prisão não tem conseguido reeducar e reintegrar o infrator depois de passar um determinado período cumprindo a sentença privativa de liberdade (PASSENTI, 2004).

É justamente nesse momento que é preciso ir muito além da positividade da norma para se discutir o fenômeno da reincidência criminal em uma realidade como a brasileira. O elo entre a norma e a realidade social precisa estar adiante de uma relação simplista estabelecida pelos estudiosos do Direito. É preciso de profundidade nessa compreensão, que só é possível de ser atingida por meio de uma transdisciplinaridade, especialmente entre as Ciências Sociais e Humanas. No caso do fenômeno da reincidência criminal, analisar o contexto político, econômico, social e comportamental por meio de vários vieses é essencialmente importante, visto que já se sabe que o cumprimento da pena não traz efeitos inibidores para a prática da reincidência, porém o que não fica claro é em que medida a prisão e outros elementos do convívio em sociedade colocam o egresso em condição de reincidente na prática criminosa.

Nesse contexto, não há como falar em reincidência criminal sem considerar os aspectos objetivos e subjetivos da vida dos egressos, por exemplo, as condições de trabalho e emprego, os riscos e a vulnerabilidade social, a relação e estrutura familiar, além da sua percepção de mundo e da realidade, valores e características culturais. A forma com que a sociedade encara o indivíduo que já cumpriu uma pena privativa de liberdade também adentra como importante elemento que deve ser considerado nessa análise. O fato é que o Direito, sozinho, não apresenta instrumentos teórico-metodológicos capazes de considerar todas estas ques- 


\section{Humanos e}

Democracia

tões que determinam como o instituto da reincidência criminal vem se comportando na realidade brasileira. Desse modo, uma visão pura deste instituto enquanto lei é, ao mesmo tempo, uma visão segregada da realidade que o envolve, o que precisa ser superado para que a lei e a realidade social sejam compatíveis mutuamente e apreensíveis dentro do plano lógico das pesquisas na área.

Vários autores na área do Direito reconhecem a expressiva relação entre a reincidência criminal e as condições adversas que envolvem a realidade social da população das diferentes regiões brasileiras. Rodrigues (2010) aponta a desagregação familiar, a influência de vícios, a falta de oportunidade de trabalho e a ineficiência no processo de ressocialização na prisão como elementos do fenômeno que explicam os altos índices de reincidência. Outras análises acerca desse processo, como a de Sapori, Santos e Maas (2017), associam ao sexo masculino a maior probabilidade de reincidir, além de que quanto mais jovem, mais vulnerável ao retorno da prática criminosa. Os crimes contra o patrimônio, como o furto, também são igualmente destacados na descrição do perfil do egresso, visto que muitos desses indivíduos apresentam uma espécie de carreira na prática criminosa, sendo contraventores habituais do mesmo crime.

De acordo com o relatório do Instituto de Pesquisas Econômicas Aplicadas (IPEA, 2015) em parceria com o Conselho Nacional de Justiça, a reincidência criminal apresenta grande relação com um determinado perfil dos apenados. Nesta pesquisa constata-se que $51 \%$ dos egressos são formados por negros e pardos e $80 \%$ deles, analfabetos. De acordo com o mesmo documento, o processo de reintegração do criminoso à sociedade é burlado, entre outros fatores, pelas próprias características do sistema penitenciário sem estrutura e prisões superlotadas no país. Os tipos de crimes perpetrados e as ações voltadas à reintegração social também são ressaltados. Outro elemento analisado no correspondente relatório diz respeito às percepções tanto dos operadores do Direito quanto dos apenados reincidentes acerca do instituto da reincidência criminal, o que, de certo modo, aproxima este relatório desta pesquisa científica, mesmo se tratando de uma realidade empírica pontual.

\section{PERCURSO DE INVESTIGAÇÃO}

Trata-se de uma pesquisa de abordagem qualiquantitativa que é caracterizada pela utilização de procedimentos tanto qualitativos quanto quantitativos, reconhecendo as suas respectivas potencialidades e limitações. Nesta pesquisa buscou-se ao mesmo tempo a compreensão concreta e empírica dos dados, bem como uma dimensão fenomenológica e subjetiva de informações. Considera-se como dados os constituintes mais quantitativos e mensuráveis adquiridos na pesquisa; já as informações correspondem à dimensão qualitativa e de interpretação do pesquisador, tendo na análise subjetiva o ponto de partida (GASKELL, 2002).

Atualmente, na área do Direito, existe um grande desafio metodológico na definição de critérios, estabelecimentos de fontes de coleta e organização de resultados, especialmente de pesquisas empíricas. É nesse sentido que a interdisciplinaridade é apontada como uma possibilidade de superação de tal questão, haja vista a necessidade de associação de várias áreas do conhecimento na investigação científica em Direito, associando problemáticas jurídicas e sociais que não podem ser avaliadas numa perspectiva unilateral (ADEODATO, 1996). 
Sendo assim, considerando a complexidade dos objetivos aqui propostos, estruturou-se uma revisão teórico-metodológica e doutrinária na qual se buscou atender aos principais conceitos, teorias e problemáticas acerca da reincidência criminal. Na sequência foram desenvolvidos os seguintes procedimentos metodológicos: a) caracterização do ambiente de estudo; b) levantamento documental; c) aplicação de questionários. Estes procedimentos foram adotados a partir de diferentes autores, respeitando processos e critérios que maximizassem a compreensão empírica dos processos analisados. Por conseguinte, as informações foram submetidas à análise de conteúdo para a correspondente elaboração e sistematização dos resultados obtidos.

\subsection{Caracterização do Ambiente de Estudo}

A Penitenciária Padrão Regional de Campina Grande-PB foi inaugurada em 2010 como estabelecimento prisional de segurança máxima com capacidade para abrigar 150 presos com pena de natureza definitiva (Figura 1), no entanto, devido a modificações no âmbito administrativo, determinadas pela Secretaria de Administração Penitenciária do Estado da Paraíba, a PPRCG passou da condição de penitenciária para presídio, ficando incumbida, assim, de abrigar presos provisoriamente em regime fechado.

\section{Figura 1 - Localização da Penitenciária Padrão Regional de Campina Grande-PB}

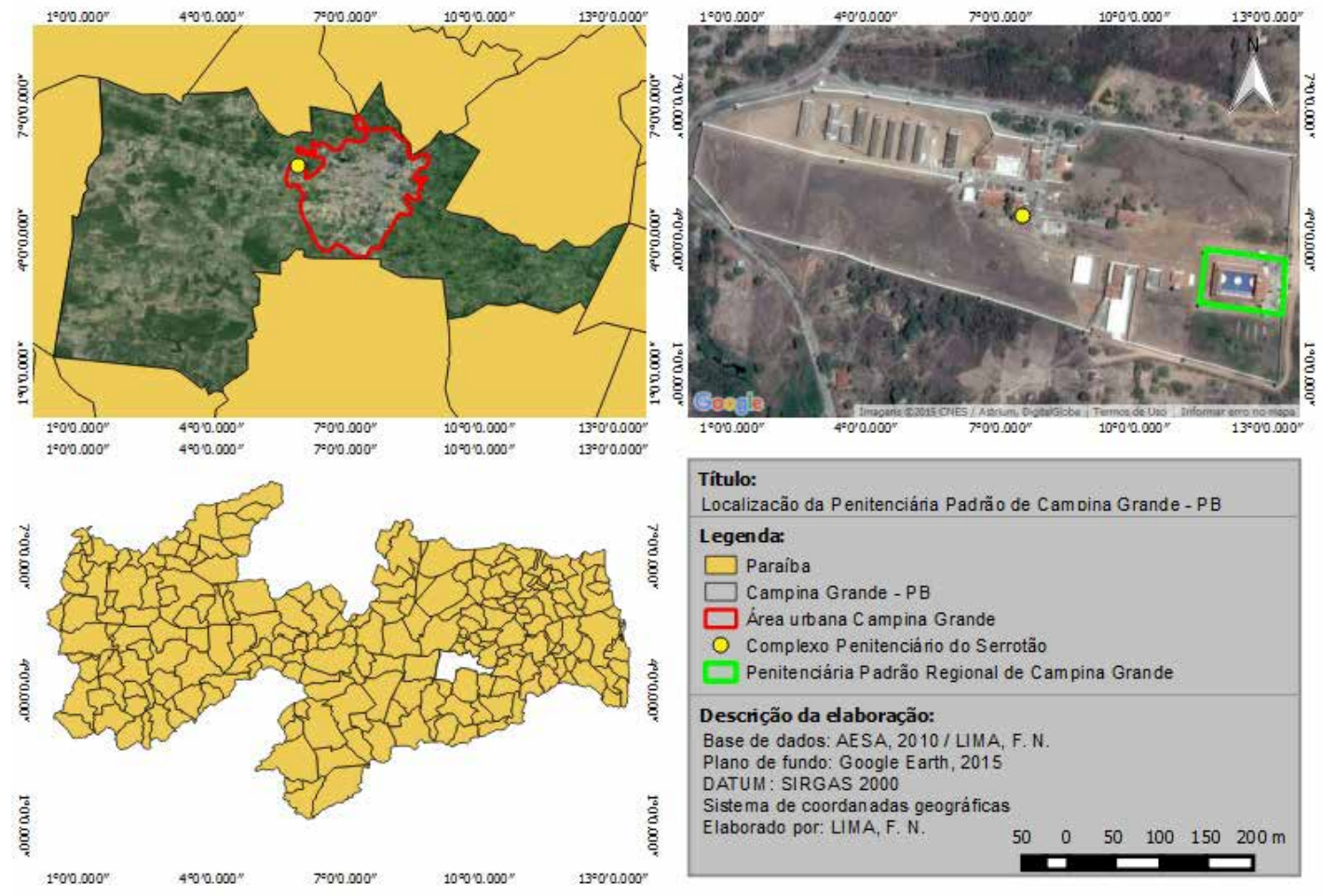

Fonte: Os autores.

Situada dentro do complexo penitenciário do Serrotão, a PPRCG, como a maioria dos presídios brasileiros, encontra-se em situação de superlotação. Atualmente este presídio conta com um total de 40 celas distribuídas em dois pisos sobrepostos. Entre os pavimentos, construídos em forma de retângulo, existe uma área destinada à prática esportiva que também serve como pátio da unidade destinado a diversas outras atividades cotidianas. 


\section{Humanos e \\ Democracia}

A área frontal da instituição, por sua vez, é destinada às repartições de gestão e manutenção do presídio. É nesse local que se encontra o refeitório, a cozinha, os alojamentos, o almoxarifado, a coordenação, os parlatórios, o setor médico, o setor jurídico, as celas destinadas aos presos que prestam serviço à Unidade, as salas de revista íntima e a direção.

\subsection{Levantamento Documental}

Esta etapa teve como intuito a identificação do quantitativo de reincidentes da PPRCG, bem como dos tipos de crimes perpetrados pelos apenados. Assim, inicialmente foi solicitado ao setor administrativo do correspondente estabelecimento prisional a relação de todos os presos existentes, considerando que não dispunham de relações específicas, por exemplo, dos apenados reincidentes.

A partir de então deu-se início à consulta no Sistema Processual do Tribunal de Justiça do Estado da Paraíba por meio do nome dos apenados. No total foram consultados 549 processos buscando identificar quais destes correspondiam a reincidentes criminais mediante sentenças transitadas e julgadas.

Além da identificação do quantitativo de presos reincidentes, foram levantados também os tipos de crimes praticados por estes sujeitos, tendo como objetivo obter um diagnóstico associando a situação de reincidência a determinados tipos de crimes. Esta questão corresponde às primeiras discussões acerca da pesquisa.

Logo, na busca pelo indicativo da reincidência desses indivíduos, foram verificados os processos existentes em nome destes, partindo-se posteriormente para uma busca mais acurada da movimentação processual, tanto no que diz respeito ao trânsito em julgado de sentença penal condenatória quanto ao tipo de crime objeto da análise processual penal.

\subsection{Aplicação de Questionários}

Os questionários tiveram como objetivo compreender como os reincidentes da PPRCG, bem como a sociedade civil, percebem os fatores inibidores e propulsores da reincidência criminal. Esta técnica de coleta de dados e informações foi baseada nas ideias de Nogueira (2002). Assim, optou-se pela utilização do questionário aberto, haja vista a vantagem que este possui em explorar todas as possíveis respostas dos indivíduos, tendo potencial, inclusive, para servir de base para elaboração de roteiros de outras técnicas de pesquisa.

Tendo em vista os dois grupos de populações que se pretende analisar, foram desenvolvidos dois questionários que seguiram critérios de elaboração e aplicação diferenciados. No que respeita ao questionário dirigido à sociedade civil, encontra-se dividido em três etapas principais: identificação do pesquisado; fatores que consideram como inibidores da reincidência criminal e fatores que consideram como propulsores da reincidência criminal.

Quanto à aplicação destes questionários, seguiu-se o modelo de amostragem por julgamento (APPOLINÁRIO, 2006), o qual possibilitou a escolha de áreas específicas no município de Campina Grande-PB para a realização da atividade. Considerando o nível de circulação de pessoas pelos espaços públicos definidos: Parque da Criança, Praça da Bandeira, Praça Clementino Procópio, Avenida Juscelino Kubitschek e Terminal de Integração (Figura 2), foram 
aplicados um total de 250 questionários (50 em cada espaço público descrito) com indivíduos que, primeiramente, se dispuseram a participar da pesquisa, e que apresentavam idade igual ou superior a 18 anos.

Figura 2 - Locais de aplicação dos questionários com a população na cidade de Campina Grande-PB

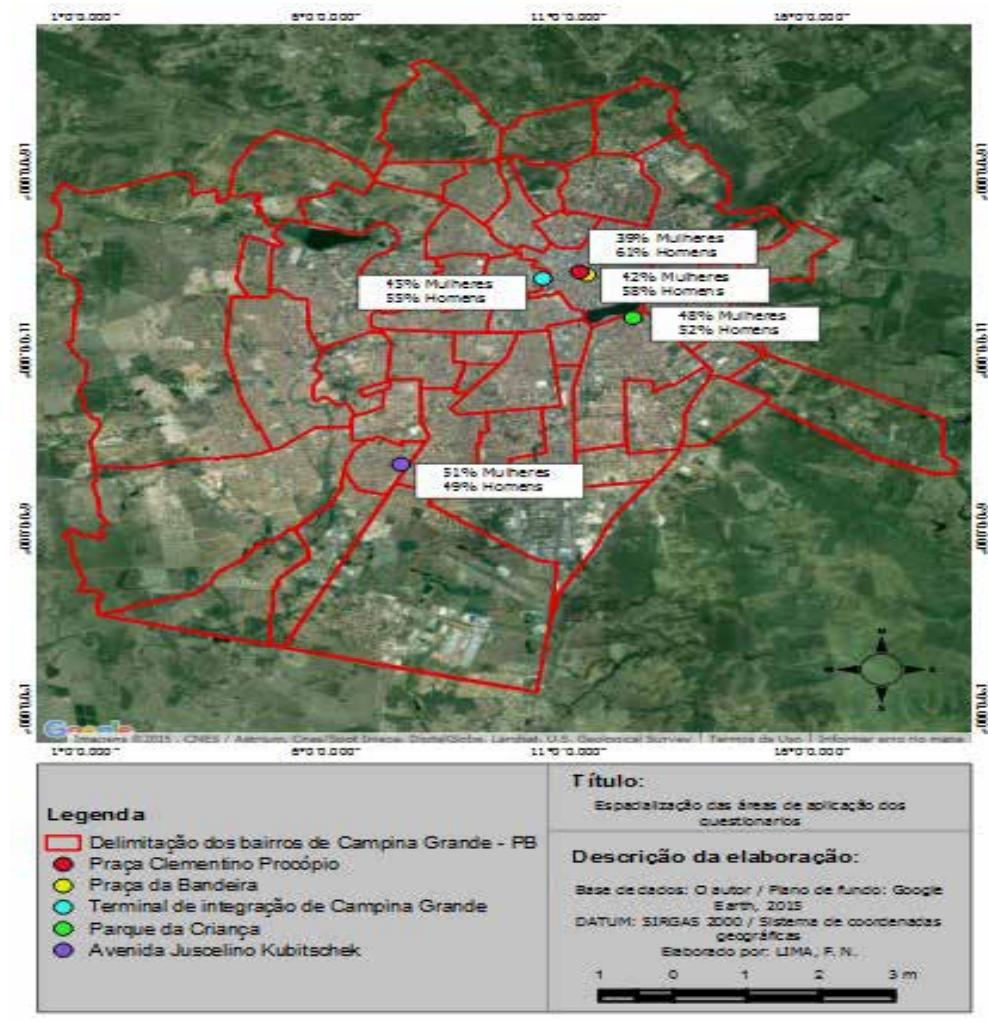

Fonte: Os autores.

Os questionários destinados aos apenados reincidentes, por sua vez, foram divididos em cinco partes: identificação do apenado; relação familiar; condições do presídio; fatores gerais que inibem a reincidência e fatores gerais que promovem a reincidência. Foram aplicados 53 questionários correspondentes ao número total da população de reincidentes da PPRCG. Vale ressaltar que este processo foi efetivado por um período de cinco dias não sequenciais, com o apoio da direção do presídio e dos agentes penitenciários ali atuantes, respeitando todas as medidas de segurança determinadas.

\section{OS INIBIDORES E PROPULSORES DA REINCIDÊNCIA CRIMINAL: OS DISCURSOS DA SOCIEDADE E DOS APENADOS REINCIDENTES EM FOCO}

\subsection{Os Reincidentes da Penitenciária Padrão Regional de Campina Grande-PB}

Inicialmente evidencia-se uma variação de cinco tipos de crimes praticados pelos reincidentes da PPRCG. No total foram identificados 50 reincidentes, dos quais $45 \%$ foram condenados por roubo (artigo 157 do CPB), 20\% por tráfico de drogas (artigo 33 da Lei 11.343/06), 20\% furto (artigo 155 do CPB), 10\% homicídio (artigo 121 do CPB) e 5\% latrocínio (artigo 157, §2ㅇdo CPB). 


\section{Humanos e \\ Democracia}

Percebe-se que o roubo foi o crime praticado pela grande maioria dos reincidentes participantes desta pesquisa. O tráfico de drogas e o furto ficaram em segundo lugar, seguidos pelo homicídio e o latrocínio, respectivamente. Nesse sentido, a situação de reincidência criminal está associada, sobretudo, com a prática do roubo de acordo com a realidade dos apenados investigados.

Corroborando esta hipótese, Santana (2014) analisa o levantamento realizado pela Secretaria de Segurança Pública do Estado de São Paulo, que afirma que de cada 10 assaltantes, 7 voltam a cometer o mesmo crime. Ou seja, o autor evidencia que além do roubo se apresentar como o principal crime que leva à reincidência, existe uma continuação da mesma prática delituosa. Logo, a tentativa de obtenção de lucro fácil e rápido, sem necessariamente a existência de procedimentos que exprimam uma organização e estudo da prática criminosa, pode ser indicada como uma explicação para este fato. Além disso, vários outros levantamentos estatísticos apontam, por exemplo, uma relação entre o aumento do número de roubos com a dependência de drogas, o que agrava ainda mais a situação criminal.

Assim, a reincidência criminal no Brasil é objeto de inúmeras teses que relacionam esta problemática a vários elementos, entre os quais se destacam as condições socioeconômicas e a negligência do Estado no cumprimento do seu papel de ressocializador por meio, especialmente, do sistema penitenciário. A partir de então, destaca-se a importância na compreensão de como se constituem os discursos acerca desta questão por parte da sociedade civil, mas também dos próprios apenados reincidentes, visto os contextos e experiências vivenciadas por esses sujeitos.

\subsection{A Reincidência Criminal na Percepção da Sociedade Civil}

No que se refere à sociedade civil do locus de pesquisa - a cidade de Campina Grande-PB - observou-se uma série de itens representados em diferentes proporções nos questionários aplicados. Com base nas indicações organizacionais de Franco (2005), além da organização, leitura e observação geral dos questionários, foi realizada uma categorização definida pelo agrupamento por tema dos diferentes itens destacados pela sociedade civil na coleta das informações.

Ademais, foi possível constatar por meio desses processos metodológicos tanto a totalidade e descrição dos itens destacados como os inibidores e propulsores da reincidência criminal quanto os níveis em que cada um destes itens foram observados na percepção popular. Foram reconhecidos três níveis de destaque: baixo, médio e alto. $\mathrm{O}$ nível baixo corresponde ao mínimo destaque do respectivo elemento indicado como inibidor ou promotor da reincidência em alguns dos locais nos quais foram aplicados questionários. O nível médio refere-se aos itens destacados em todos os locais de aplicação dos questionários com pelo menos $30 \%$ da população. Já o nível alto corresponde ao destaque em todos os locais de aplicação com no mínimo $50 \%$ dos participantes.

Logo, foram analisados os itens designados como os principais inibidores e propulsores da reincidência criminal, bem como os níveis em que estes se apresentaram na percepção social da população da cidade de Campina Grande-PB (Quadro 1). 
Quadro 1 - Análise de conteúdo dos questionários aplicados com a sociedade civil

\begin{tabular}{|c|c|c|}
\hline \multicolumn{2}{|c|}{ Itens destacados na percepção popular } & Nível de destaque \\
\hline \multirow{9}{*}{$\begin{array}{l}\text { Propulsores da } \\
\text { reincidência } \\
\text { criminal }\end{array}$} & Péssimas condições do presídio & \\
\hline & Insuficiência das políticas de ressocialização & \\
\hline & Convívio com outros tipos de criminosos & \\
\hline & Ausência de perspectivas futuras & \\
\hline & Preconceito com o ex-detento & \\
\hline & Falta de emprego & \\
\hline & Características pessoais do apenado & \\
\hline & Dependência de substâncias psicoativas & \\
\hline & Ausência de Deus & \\
\hline \multirow{5}{*}{$\begin{array}{l}\text { Inibidores da } \\
\text { reincidência } \\
\text { criminal }\end{array}$} & Oportunidade de emprego & \\
\hline & Possibilidade de profissionalização do detento & \\
\hline & Investimentos em educação básica e profissionalizante & \\
\hline & Incentivo da sociedade ao apenado & \\
\hline & Mudança na legislação penal (penas mais severas) & \\
\hline
\end{tabular}

\begin{tabular}{|c|c|}
\hline \multicolumn{2}{|c|}{ Legenda: Níveis } \\
\hline Baixo & \\
\hline Médio & \\
\hline Alto & \\
\hline
\end{tabular}

Fonte: Os autores.

Em um primeiro momento ressalta-se que as péssimas condições do presídio, a insuficiência das políticas públicas de ressocialização, o convívio dos apenados com outros tipos de criminosos e a falta de emprego foram os propulsores referidos em maior nível de destaque por parte da sociedade civil. Este cenário está associado ao reconhecimento por parte da população dos resultados desastrosos que a função punitiva da pena revela, além da insuficiente atuação do Estado na proteção e promoção dos direitos básicos dos cidadãos.

Nesse contexto, Kneipp (2012) explica que por um lado, por meio de um alarde social, a população anseia por uma punição mais rígida para o sujeito que volta a praticar o crime. A sociedade, no entanto, também responsabiliza o Estado pelas elevadas taxas de reincidência no país, sobretudo, por intermédio do sistema penitenciário. Assim, de acordo com este pressuposto, o reincidente acaba se tornando uma "vítima" da própria ineficiência do Estado, porém precisa ser penalizado de forma mais dura para garantir as exigências do ordenamento jurídico brasileiro, não desencadeando um sentimento de impunidade.

O preconceito com o ex-detento, as características pessoais destes sujeitos e a dependência de substâncias psicoativas foram ressaltados como propulsores da reincidência em nível médio. A partir de então, observa-se uma responsabilização pela situação de reincidência ao próprio apenado e à sociedade. Logo, é assegurado que os indivíduos acabam desenvolvendo comportamentos e características eticamente reprováveis condicionados pelo seu próprio contexto social. No que se refere ao apenado, a população associa características como a preguiça, uma predisposição a atitudes perversas, maldade e desinteresse por estudo e trabaIho. Nesse sentido, o reincidente é visto como o grande responsável pela sua situação criminal devido ao poder de escolha, mesmo podendo existir uma série de fatores que aumentem 


\section{Humanos e}

Democracia

as chances destes cometerem crimes. Sartre (2000) corrobora essa discussão à medida que sugere uma responsabilização do indivíduo sobre suas ações, visto que para ele o ser não é determinado apenas pelo que fazem dele, mas pelo que se faz do que fazem dele.

A dependência de drogas, de acordo com a sociedade civil, está voltada à situação socioeconômica, mas também exprime as características pessoais do apenado reincidente que, muitas vezes, para cometer os crimes faz uso destas substâncias. Por outro lado, o estigma de ex-presidiário faz com que a sociedade desenvolva uma indisposição para estabelecer o convívio com estes sujeitos, o que também promove a reincidência na percepção da população participante desta pesquisa. Não obstante, este preconceito com os ex-detentos gera uma necessária política de inclusão social destes sujeitos, principalmente no mercado de trabalho. A partir disso, Brandão e Farias (2013) afirmam que a efetiva recuperação do ex-detento e sua inserção social só ocorrerão quando estes sujeitos forem recebidos livres de preconceitos pela sociedade civil.

No que tange aos propulsores da reincidência destacados nos níveis mais baixos, destacam-se a ausência de perspectivas futuras e de Deus. Esta parcela dos pesquisados afirmaram que o egresso, por diversas circunstâncias, desenvolve uma situação psicológica difícil que Ihe impossibilita de desenvolver planos e perspectivas em curto e longo prazos. A ausência de Deus por meio de uma distância com qualquer tipo de prática religiosa também foi um fator descrito, visto que o sujeito não se atenta a regulamentações e ideologias que poderiam fazê-lo refletir em um momento anterior à prática delituosa, impedindo-a. Em uma pesquisa acerca das perspectivas do egresso, Pinto e Hirdes (2006) apontam que a principal dificuldade para a reabilitação do apenado corresponde à ausência de perspectivas de vida e de um direcionamento capaz de mudar suas práticas. De acordo com esse estudo, os apenados que possuem maiores chances de reabilitação são justamente os que dispõem de mecanismos que viabilizam uma condição psicológica favorável, como a vontade de se reabilitar e de não assumir uma identidade criminal reincidente na própria instituição e fora dela.

No que se refere aos inibidores da reincidência criminal na percepção popular, em alto nível de destaque está a oportunidade de emprego, a possibilidade de profissionalização do detento e os investimentos em educação básica e profissionalizante. Assim, percebe-se a existência de elementos no discurso da população que ora é visto como um propulsor da reincidência, ora como um inibidor. Por exemplo, a ausência de emprego é vista como um propulsor da reincidência, enquanto a oportunidade de emprego foi ressaltada como um inibidor.

$\mathrm{Na}$ literatura encontra-se uma grande quantidade de trabalhos que destacam a ausência de emprego como um elemento-chave para a promoção da reincidência. De forma específica, de acordo com o relatório de pesquisa do Instituto de Pesquisa Econômica Aplicada e o Conselho Nacional de Justiça (IPEA, 2015), a questão do emprego é um dos principais aspectos ressaltados quando se trata da reincidência criminal. A oportunidade de retorno ou ingresso ao mercado de trabalho, sob a ótica deste documento, além de garantir a subsistência do indivíduo, eleva a sua moral e autoestima. Para tanto, fica evidente a necessidade de investimentos em políticas de profissionalização do detento e na educação básica e profissionalizante, sobretudo das áreas de vulnerabilidade social, o que também apareceu em alto nível de destaque nesta análise. 
Em continuidade, a mudança na legislação penal, pela existência de penas mais severas aos reincidentes, foi um elemento enfatizado em nível médio. Este fato, a priori, levanta uma dualidade em que parte da população aponta a responsabilização dos inibidores da reincidência para - Estado por meio de políticas de previnam a situação criminal, enquanto outra parcela acredita que penas mais severas, sobretudo mais longas, poderiam servir como inibidores das práticas criminosas. É sabido que a situação da reincidência, compreendida como circunstância agravante obrigatória, também acarreta outros efeitos penais que aumentam o rigor do tratamento ao réu, de modo que este conhecimento não foi percebido no discurso desta parcela populacional.

O incentivo por parte da população ao apenado, por sua vez, apareceu em nível baixo de destaque. Nesse sentido, a possibilidade de reconstrução de vida por meio de novas práticas e convívio social também dependerá de uma nova oportunidade ofertada ao apenado, sem a qual as chances de este sujeito retornar às práticas ilícitas são ampliadas. O incentivo, nesse contexto, corresponde ao encorajamento e estímulo por parte da sociedade a um novo modo de vida que esteja, acima de tudo, dentro da legalidade.

\subsection{A Reincidência Criminal na Percepção dos Apenados Reincidentes}

Seguindo, inicialmente, o mesmo processo e classificação metodológica dos inibidores e propulsores da reincidência na percepção da população, foram analisados os questionários aplicados com os apenados reincidentes da PPRCG. Assim, foram destacados os itens abordados como propulsores e inibidores da reincidência e os níveis em que cada um se apresentou na análise de conteúdo a fim de garantir a compreensão do real entendimento dos apenados acerca do tema em questão (Quadro 2).

Quadro 2 - Análise de conteúdo dos questionários aplicados com os apenados reincidentes

\begin{tabular}{|c|c|c|}
\hline \multicolumn{2}{|r|}{ Itens destacados na percepção dos apenados } & Nível de destaque \\
\hline \multirow{10}{*}{$\begin{array}{l}\text { Propulsores da } \\
\text { reincidência } \\
\text { criminal }\end{array}$} & Condições do presídio & \\
\hline & Convívio com outros criminosos & \\
\hline & Falta de emprego & \\
\hline & Falta de políticas do governo & \\
\hline & Dependência de drogas & \\
\hline & Nenhuma condição financeira & \\
\hline & Tráfico de drogas & \\
\hline & Falta de apoio da sociedade & \\
\hline & Preconceito & \\
\hline & Revolta pela lentidão do processo & \\
\hline \multirow{6}{*}{$\begin{array}{l}\text { Inibidores da } \\
\text { reincidência } \\
\text { criminal }\end{array}$} & Relação familiar & \\
\hline & Possibilidade de emprego & \\
\hline & Sentimento de insegurança física e mental no presídio & \\
\hline & Inimizades dentro do presídio & \\
\hline & Situação de encarceramento & \\
\hline & Condições do presídio & \\
\hline
\end{tabular}

\begin{tabular}{|c|c|}
\hline \multicolumn{2}{|c|}{ Legenda: Níveis } \\
\hline Baixo & \\
\hline Médio & \\
\hline Alto & \\
\hline
\end{tabular}




\section{Humanos e}

Democracia

No que tange aos propulsores da reincidência criminal destacados em maiores níveis, encontram-se as condições do presídio, o convívio com outros criminosos, a falta de emprego e de políticas do governo, de modo que estes elementos também foram indicados na percepção da população.

Os apenados ressaltaram a incapacidade estrutural do presídio para comportar a quantidade de presos, não subsidiando necessidades e direitos básicos, como uma boa alimentação, acesso à água e a um ambiente com todas as condições de organização e higiene necessárias. Utilizando essas mesmas justificativas, no entanto, as condições do presídio também foram ressaltadas como inibidores da reincidência à medida que, para alguns, aquele é um ambiente de repulsa que merece todo esforço para não ser vivenciado. Logo, aponta-se para toda uma complexidade em torno desta questão, uma vez que para parte dos pesquisados a ausência das condições ideais favorece o retorno do apenado pela inexistência de um ambiente ressocializador, enquanto para outros este fato demonstra ainda mais o ambiente hostil que pode ser enfrentado em caso de retorno à prática criminosa.

Figueiredo Neto et al. (2009) levantam a discussão sobre a situação calamitosa do sistema penitenciário brasileiro, haja vista principalmente a superlotação dos presídios e a incapacidade de gerenciar um sistema guiado pelos dois eixos da Lei de Execução Penal: punir e ressocializar. Sendo assim, percebe-se que mesmo não querendo retornar ao presídio pelas péssimas condições ofertadas, o apenado não foi ressocializado por estas mesmas condições, o que, em tese, não permite incluir as péssimas condições do presídio como um fator que inibe a prática delituosa. Ademais, o próprio convívio com outros criminosos acentua ainda mais esse contexto de não ressocialização em alto nível de destaque. A falta de emprego, na sequência, expressa um contexto vivenciado fora do presídio. $O$ estigma de ex-presidiário é o principal fator responsável pela falta de emprego, que em determinadas situações políticas e econômicas se mantém escasso para grande parcela populacional, aumentando a situação de vulnerabilidade social.

Em nível médio de destaque está a falta de políticas do governo, a dependência de drogas, a falta de apoio da sociedade e o preconceito. Logo, percebe-se que assim como a sociedade civil, os apenados reincidentes também apontam como propulsores da reincidência fatores ligados diretamente ao papel do Estado, como a ausência de políticas de ressocialização dentro e fora do presídio. Foram evidenciados, porém, aspectos relacionados à falta de apoio e ao preconceito da sociedade com o ex-detento, o que está relacionado a uma cultura de exclusão muito complexa e ancorada ora na responsabilização do Estado sobre o indivíduo, ora na responsabilização do indivíduo sobre ele mesmo.

Finalizando os propulsores, constatou-se em baixo nível de destaque a falta de condição financeira, o tráfico de drogas e a revolta pela lentidão do processo. É importante destacar que no discurso dos apenados estes problemas possuem uma interdependência muito concreta, de modo que a falta de dinheiro acarreta o ingresso no mundo do tráfico, por exemplo. Outra questão é que o apenado percebe situações específicas como propulsores do seu retorno à instituição prisional, como é o caso da lentidão na tramitação do processo. De acordo com os presos, a ineficiência da Justiça quanto à forma de condução e julgamento do processo gera um sentimento de revolta que pode contribuir para o retorno do egresso à prisão. 
Os inibidores da reincidência criminal destacados em alto nível foram a relação familiar, a possibilidade de emprego, o sentimento de insegurança dentro do presídio e as inimizades na instituição prisional. A relação familiar surge como um elemento muito importante no discurso do apenado. De acordo com estes sujeitos, a família é o aspecto mais importante para não se praticar o crime, embora tenham retornado a esta situação. A totalidade dos pesquisados afirmou apresentar uma relação de boa a ótima com seus familiares, revelando-se este um fator inibidor, porém não determinante, para a sua conduta criminal.

A possibilidade de emprego, como já discutido, é elemento-chave para o egresso retornar à sociedade sem, necessariamente, oferecer risco, no entanto a situação é exatamente contrária, caracterizada pela falta de emprego devido ao preconceito, como foi destacado anteriormente nos fatores propulsores. Todos os apenados participantes da pesquisa relataram como principal problema da sua situação a falta de emprego e oportunidades profissionais.

O sentimento de insegurança física e mental, por sua vez, justifica o fato de o presidiário não querer retornar à instituição por temer pela sua sanidade mental e até mesmo pela vida. A estrutura precária, nesse sentido, seria a responsável por este fator que não favorece a ressocialização do apenado, apenas desenvolve um ambiente ainda mais difícil e vulnerável para o egresso. Os participantes da pesquisa expressaram uma visão muito particularizada dos fatores que fazem com que eles não queiram retornar ao presídio a partir de suas experiências e situações. Nesse viés, as inimizades com presidiários adquiridas dentro e fora do presídio foi o último elemento destacado em alto nível quanto aos inibidores da reincidência. Este fato reflete-se em uma série de outras situações que envolvem as características pessoais dos apenados, dívidas, brigas entre gangues rivais e por território.

As condições do presídio foram ressaltadas em nível médio como um inibidor da reincidência, questão também já mencionada anteriormente. Por fim, a situação de encarceramento por meio da privação da liberdade do indivíduo foi destacada em baixo nível pelos apenados. Este item foi indicado no sentido de que o indivíduo não pode escolher os locais nos quais vai permanecer ou não. A impossibilidade de vivenciar lugares diferenciados e a dinamicidade do cotidiano fora do presídio é algo que estes apenados destacaram como elementos importantes para não retornar à prática do crime.

As representações acerca dos inibidores e propulsores da reincidência criminal variaram entre os discursos da sociedade civil e dos apenados reincidentes da PPRCG. As responsabilizações pela promoção e inibição da reincidência, em geral, oscilaram entre o contexto dos problemas sociais e políticos enfrentados no país, até questões específicas das experiências de vida do apenado. Diante disto, faz-se necessário discutir as oposições e complementaridades dos discursos com o objetivo de reconhecer a amplitude do problema em questão, visto que é a partir de uma variação de elementos, como as condições de vida, as relações sociais e a própria experiência prisional, que é possível explicar a situação de reincidência, Logo, parte-se do pressuposto de que se limitar à análise de apenas uma das percepções investigadas (sociedade civil e/ou apenados reincidentes) pode negligenciar as reais explicações da reincidência, uma vez que esta não é resultado apenas da experiência prisional, tampouco somente da história de vida do indivíduo. 


\section{Humanos e \\ Democracia}

\subsection{Visões Acerca dos Propulsores e Inibidores da Reincidência: Oposições e Complementaridades}

Quando comparadas as percepções da sociedade civil e dos apenados reincidentes acerca dos propulsores da reincidência criminal, houve um nível de concordância de elementos bastante considerável. A sociedade civil destacou nove aspectos relacionados à promoção da reincidência, enquanto os apenados destacaram dez, no entanto seis destes elementos foram citados pelas duas populações da pesquisa, conforme se observa na Figura 3.

Figura 3 - Modelo explicativo dos propulsores da reincidência criminal na percepção da sociedade civil e dos apenados

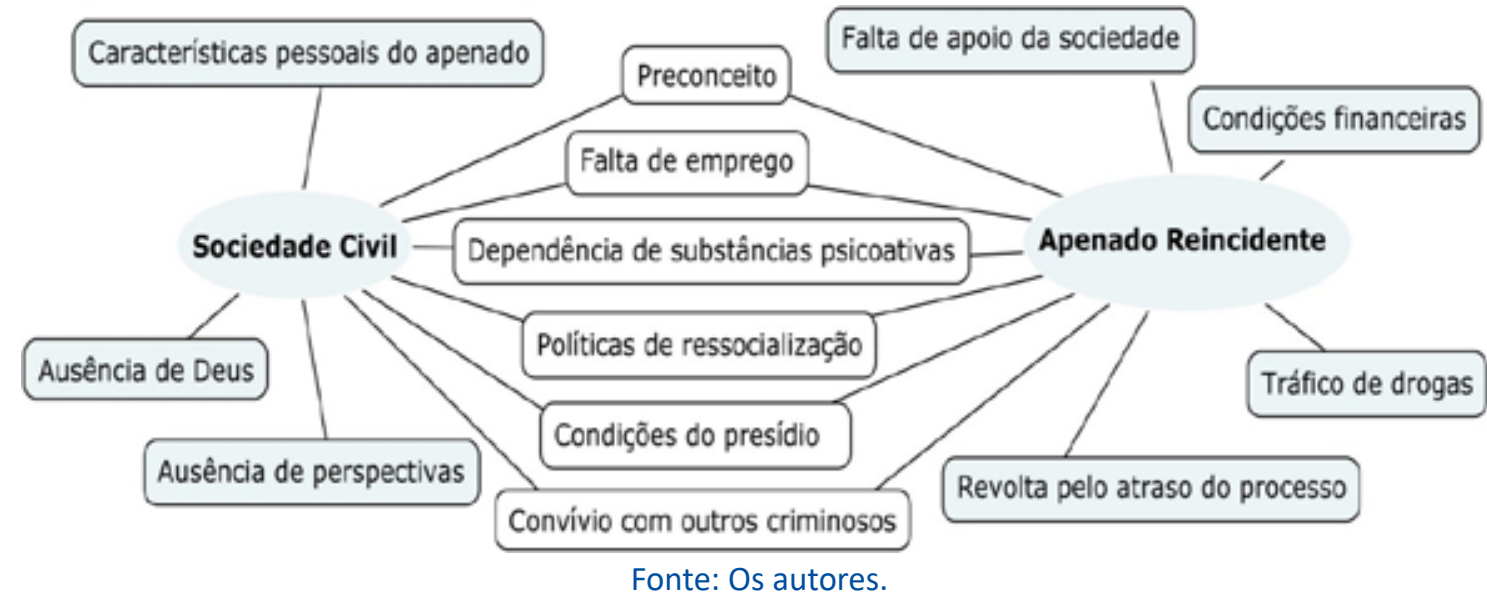

No que se relaciona aos elementos propulsores da reincidência criminal, o preconceito, a falta de emprego, a dependência de substâncias psicoativas, as políticas de ressocialização, as condições do presídio e o convívio com outros criminosos foram os elementos coincidentes entre os dois discursos. Isto revela que é sabido pelos dois universos da pesquisa que o problema do aumento continuado da reincidência não envolve apenas as condições do presídio e a ausência do Estado, mas também o preconceito sofrido pelo ex-detento estigmatizado pela sociedade de modo geral.

A sociedade levanta também uma discussão que acaba por responsabilizar o próprio apenado pela sua situação de reincidente. Neste ponto, percebe-se que a população considera que existem determinadas características do próprio sujeito que o levam à prática do crime, que nem sempre é explicada por uma questão social. A ausência de perspectivas e de Deus também remetem a uma ligação da prática criminosa ao próprio apenado, tanto por meio de um afastamento para com o divino quanto por um modo de vida sem objetivos e metas para o futuro.

Quanto aos aspectos propulsores destacados apenas pelos apenados, reafirmam-se elementos relacionados à ineficiência do Estado e da Justiça, como é o caso da revolta pelo atraso do processo e as condições financeiras. Estes sujeitos também indicaram a falta de apoio da sociedade como um aspecto que promove a reincidência, além do tráfico de drogas que determina a prática criminosa em áreas socialmente excluídas, nas quais, muitas vezes, esta é a forma mais fácil de conseguir garantir alguma renda.

Logo, a sociedade, de modo geral, destaca como propulsores da reincidência criminal tanto o Estado, pela ineficiência no processo de ressocialização, quanto o próprio apenado, que possui uma personalidade e caráter duvidosos, levando-os a desenvolver uma espécie de 
identidade criminosa. Enquanto isso os apenados, além de também destacarem a ineficiência do Estado, indicam uma responsabilização do aumento da reincidência à sociedade que, por sua vez, desenvolve um preconceito que dificulta, principalmente, a possibilidade de emprego.

Já no que se refere aos fatores inibidores da reincidência criminal o único elemento que coincidiu entre as duas populações da pesquisa foi a possibilidade de emprego. A sociedade gerou um discurso muito associado ao papel das políticas públicas na inibição da reincidência como os investimentos em educação e a possibilidade de profissionalização do detento. Além disso, foi destacado que a existência de um incentivo da sociedade também pode maximizar as chances de recuperação dos sujeitos. Por fim, a mudança na legislação penal também foi indicada. Parte dos pesquisados asseguraram que penas mais severas poderiam de alguma maneira refletir em uma queda nos índices de reincidência (Figura 4).

Figura 4 - Modelo explicativo dos inibidores da reincidência criminal na percepção da sociedade civil e dos apenados

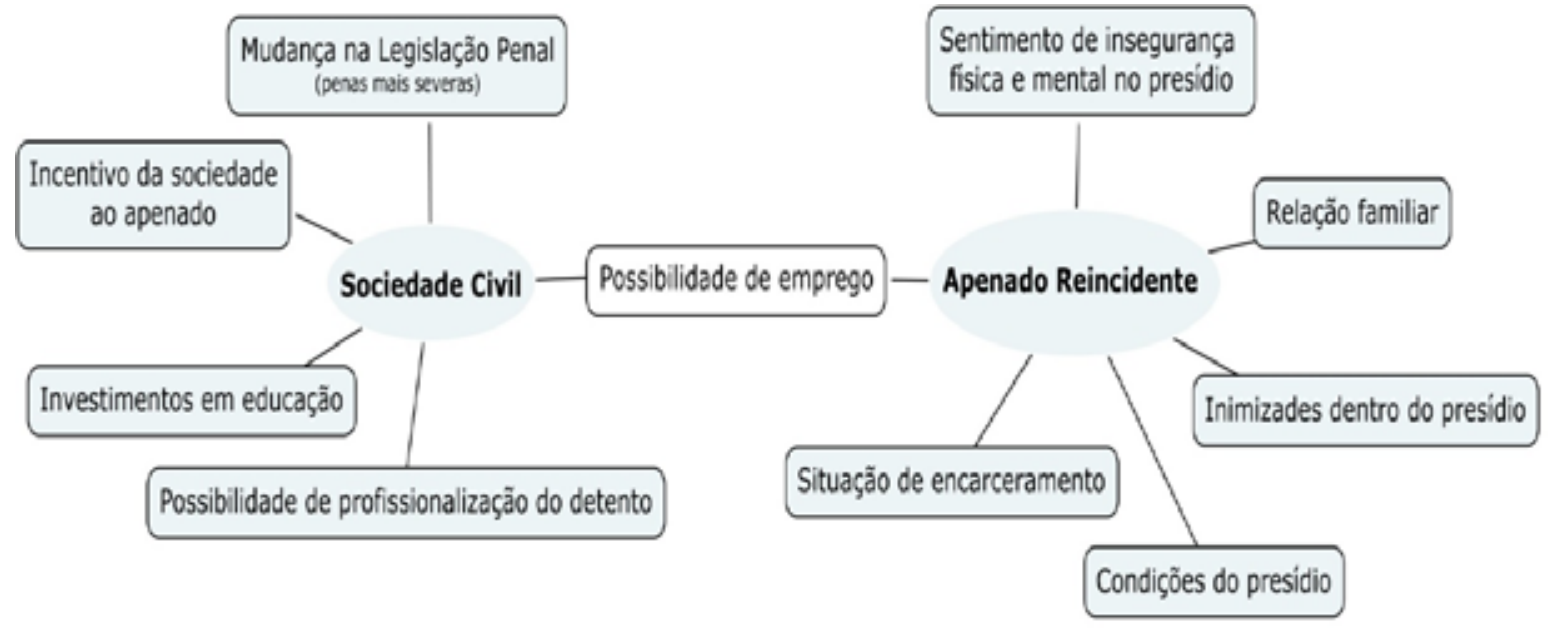

Fonte: Os autores.

Os apenados destacaram como inibidores questões de cunho pessoal, como a relação familiar, a situação de encarceramento, inimizades dentro do presídio e, mais uma vez, a ineficiência do Estado em relação às condições do presídio e do sentimento de insegurança física e mental dentro estabelecimento prisional. Nesses termos, observa-se que a sociedade civil enfatiza o papel do Estado no combate à reincidência, bem como da própria sociedade. Já o apenado descreveu características pessoais como inibidores e também responsabilizou o Estado. Logo, não foram destacados, por partes dos apenados, aspectos relacionados à sociedade como fator inibidor da reincidência criminal.

Por fim, constatam-se os diversos discursos e dilemas em torno do problema da reincidência criminal por parte da sociedade e dos apenados reincidentes da PPRCG. A partir de então, fica evidente a necessidade de contemplar várias questões, além do Direito, para se trabalhar com a reincidência, com a abordagem fenomenológica existencialista constituindo-se em uma importante possibilidade para a compreensão deste e de outros fenômenos estudados pelo Direito. Logo, é necessário reconhecer o condicionamento deste problema por parte da negligência do Estado, do preconceito da sociedade e das características de cada 


\section{Humanos e}

Democracia

apenado reincidente. O nível hierárquico em que cada um destes fatores determina os altos índices de reincidência ainda não é conhecido, fato este considerado uma importante questão de pesquisa que precisa ser trabalhada.

\section{CONSIDERAÇÕES FINAIS}

Percebeu-se que a grande complexidade do tema que envolve a reincidência criminal está associada a fatores jurídicos, políticos, sociais e culturais. No que respeita aos 50 apenados reincidentes da PPRCG, verificou-se que 45\% deste total estão associados ao roubo (artigo 157). No que se refere à percepção do apenado acerca da sua condição de encarcerado, foram destacados como propulsores os seguintes itens: condições do presídio, convívio com outros criminosos, falta de emprego, falta de políticas do governo, dependência de drogas, nenhuma condição financeira, tráfico de drogas, falta de apoio da sociedade, preconceito e revolta pela lentidão do processo. Já como fatores inibidores estes ressaltaram: relação familiar, possibilidade de emprego, sentimento de insegurança física e mental no presídio, inimizades dentro do presídio, situação de encarceramento e condição do estabelecimento prisional.

Ademais, quando comparados os discursos destes sujeitos com os da sociedade civil, coincidem como propulsores o preconceito, a falta de emprego, a dependência de substâncias psicoativas, as políticas de ressocialização, as condições do presídio e o convívio com outros criminosos. Vale ressaltar que as características pessoais do apenado, a ausência de Deus e de perspectivas foram elementos propulsores indicados apenas pela sociedade civil. No que diz respeito aos aspectos inibidores, o único elemento coincidente entre os dois discursos foi a possibilidade de emprego.

Nesse sentido, realizando uma classificação geral dos discursos, a sociedade destaca como propulsores da reincidência criminal tanto o Estado, pela ineficiência no processo de ressocialização, quanto o próprio apenado, que possui uma personalidade e caráter duvidosos, permitindo-lhe desenvolver uma espécie de identidade criminosa. Enquanto isso os apenados, além de também destacarem a ineficiência do Estado, remetem a responsabilização pelo aumento da reincidência à sociedade que, por sua vez, desenvolve um preconceito que dificulta, principalmente, a possibilidade de emprego. Como inibidor, observa-se que a sociedade enfatiza o papel do Estado no combate à reincidência, bem como dela própria. Já o apenado descreveu características pessoais como inibidores e também responsabilizou o Estado. Logo, não foram destacados, por partes dos apenados, aspectos relacionados à sociedade como fator inibidor da reincidência criminal.

\section{REFERÊNCIAS}

ADEODATO, J. M. Filosofia do direito: uma crítica à verdade na ética e na ciência (através de um exame da ontologia de Nicolai Hartmann). São Paulo: Saraiva, 1996.

ALMEIDA, S. L. Sartre: direito e política, ontologia, liberdade e revolução. 2011. 224f. Tese (Doutorado em direito) - Universidade de São Paulo, USP, São Paulo, 2011.

APPOLINÁRIO, F. Metodologia da ciência: filosofia e prática da pesquisa. São Paulo: Thomson Learning, 2006.

BARREIROS, Y. S. de A. A reincidência no sistema jurídico brasileiro. Revista Jus Navigandi, Teresina, ano $12, \mathrm{n}$. 1.626, 14 dez. 2007. Disponível em: https://jus.com.br/artigos/10763. Acesso em: 2 nov. 2017.

BOBBIO, N. Teoria do ordenamento jurídico. 6. ed. Brasília: Ed. UNB, 1995.

BRANDÃO, J. M. F.; FARIAS, A. C. de A. Inclusão social de ex-detentos no mercado de trabalho: reflexões acerca do projeto esperança viva. Anais... IV Encontro de Gestão de Pessoas e Relações de Trabalho, Brasília, Anpad, 2013. 
BRITO, R. M.; BRAGA, G. B.; SANTOS, E. O.; PRINTES, J. S.; CHAVES, R. M. T.; SILVA, W. L. A. A hermenêutica e o processo de construção do conhecimento. Dialógica, Manaus, on-line, v. 1, p. 24-38, 2007.

CAPEZ, F. Curso de Direito Penal: parte geral. 12. ed. rev. e atual. São Paulo: Saraiva, 2008. V. 1.

CLÈVE, C. M. O Direito e os direitos: elementos para uma crítica do direito contemporâneo. 2. ed. São Paulo: Max Limonad, 2001.

CHIQUEZI, A. Reincidência criminal e sua atuação como circunstância agravante. 2009. Dissertação (Mestrado em Direito) -PUC, São Paulo 2009.

COSTA, A. A. Direito e método: diálogos entre a hermenêutica filosófica e a hermenêutica jurídica. $2008.421 \mathrm{f}$. Tese (Doutorado em Direito) -Faculdade de Direito, Universidade de Brasília, UnB, Brasília, 2008.

COSTA, A. A.; COELHO, I. M.. Teoria dialética do Direito: a filosofia jurídica de Roberto Lyra Filho. 1. ed. Brasília: Faculdade de Direito, UnB, 2017. 110p. V. 1.

DESCARTES, R. Regras para a direção do espírito. Tradução J. Gama. Lisboa: Edições 70, 1985.

ECKER, D. Fenomenologia da consciência e ontologia em Sartre. 2010. 72 f. Dissertação (Mestrado em Filosofia) - UFSM, Santa Maria, 2010.

FIGUEIREDO NETO, M. V.; MESQUITA, Y. P. V. O.; TEIXEIRA, R. P.; ROSA, L. C. S. A ressocialização do preso na realidade brasileira: perspectivas para as políticas públicas. In: Âmbito Jurídico, Rio Grande do Sul, n. 65, 2009.

FRAGOSO, H. C. Lições de Direito Penal: parte geral. ed. rev. por Fernando Fragoso. Rio de Janeiro: Forense, 2004. FRANCO, M. L. B. Análise de conteúdo. Brasília: Liber Livro Editora, 2005.

GASKELL, G. Entrevistas individuais e de grupos. In: BAUER, M. W.; GASKELL. G. (org.). Pesquisa qualitativa com texto, imagem e som. Um manual prático. Petrópolis: Vozes, 2002. p. 64-89.

GRODIN, J. Introdução à hermenêutica filosófica. São Leopoldo: Editora Unisinos, 1999.

HEIDEGGER, M. Ser e tempo. 12. ed. (parte I). Trad. Márcia de Sá Cavalcanti. Petrópolis: Vozes, 2002.

HUSSERL, E. Méditations cartésiennes. Introduction à la phénoménologie. Traduit par G. Peiffer et E. Levinas. Paris: Vrin, 2001.

IPEA. Instituto de Pesquisa Econômica Aplicada. Reincidência criminal no Brasil. Relatório final de atividades da pesquisa sobre reincidência criminal, conforme Acordo de Cooperação Técnica entre o Conselho Nacional de Justiça e o IPEA. Brasília: Ipea, 2015.

2012. ) -, KELSEN, H. Teoria pura do direito. Trad. João Baptista Machado. São Paulo: Martins Fontes, 1997.

KNEIPP, Regiane Lacerda. A reincidência criminal potencializada pela falência da execução da pena privativa de liberdade. 2012. Monografia (Bacharelado em Direito) - Faculdade de Jaguariuna, São Paulo, 2012.

MAMAN, J. A. Fenomenologia existencial do direito. São Paulo: Quartier Latin, 2003.

MARQUES, J. F. Curso de Direito Penal. São Paulo: Saraiva, 1956. v. III,

MINAYO, M. C. de S. O desafio do conhecimento: pesquisa qualitativa em saúde. 8. ed. São Paulo: Hucitec, 2004.

MORIN, E. Introdução ao pensamento complexo. 3. ed. Porto Alegre: Sulina, 2007.

NADER, P. Introdução ao estudo do direito. Rio de Janeiro: Forense, 2011.

NOGUEIRA, R. Elaboração e análise de questionários: uma revisão da literatura básica e a aplicação dos conceitos a um caso real.- Rio de Janeiro: UFRJ; COPPEAD, 2002.

ORTEGA y GASSET, J. Investigações de Psicologia. Obras Completas. v. XII, 2. reimpresión, Madrid: Alianza, 1997.

PASSENTI , E. A atualidade do abolicionismo penal. Rio de Janeiro: Revan, 2004.

PINTO, G.; HIRDES, A. O processo de institucionalização de detentos: perspectivas de reabilitação e reinserção social. Esc. Anna Nery Rev. Enferm, 10(4), p. 678-683, 2006.

REALE, M. Teoria tridimensional do direito. 5. ed. São Paulo: Saraiva, 1994.

RODRIGUES, E. E. M. Egressos reincidentes: um estudo dos fatores que contribuem para a reincidência. 2010. Dissertação (Mestrado em Serviço Social) - Universidade Federal de Pernambuco, 2010.

SANTANNA, L. De cada 10 assaltantes, 7 voltam a roubar no estado e $41 \%$ são menores. Estadão. São Paulo. 26 de janeiro de 2014. Disponível em:http://saopaulo.estadao.com.br/noticias/geralde-cada-10-assaltantes-7-voltam-a-roubar-noestado-e-41-sao-menores,1123132. Acesso em: 12 ago. 2017.

SAPORI, L. F.; SANTOS, R. F. MAAS, L. W. Fatores sociais determinantes da reincidência criminal no Brasil: o caso de Minas Gerais. Rev. Bras. Ci. Soc., [on-line]. 2017, vol. 32, n. 94, 2017.

SARTRE. J. P. A náusea. Tradução Rita Braga. Rio de Janeiro: Nova Fronteira, 2000. (Coleção Grandes Romances). SARTRE. J. P. Crítica da razão dialética. Trad. Guilherme João de Freitas Teixeira. Rio de Janeiro: DP\&A Editora, 2002.

SARTRE. J. P.. O existencialismo é um humanismo. Tradução Rita Correira Guedes, Luiz Roberto Salinas Forte e Bento Prado Júnior. 3. ed. São Paulo: Nova Cultural, 1987.

SARTRE. J. P. O ser e o nada: ensaio de ontologia fenomenológica. Trad. P. Perdigão. 19. ed. Petrópolis: Vozes, 2011.

ZAFFARONI, E. R.; PIERANGELI, J. H. Manual de Direito Penal Brasileiro: parte geral. 4. ed. rev. São Paulo: Revista dos Tribunais, 2002. 